\section{ANALISIS PENGARUH DIVERSIFIKASI PRODUK ELEKTRONIK TERHADAP MINAT BELI ULANG DENGAN REPUTASI PERUSAHAAN SEBAGAI VARIABEL MODERATOR PADA UD. SABAR MENANTI DI GERUNG LOMBOK BARAT}

\author{
Mina Novianty Eka Lavionita ${ }^{1}$ \\ Budi Santoso $^{2}$ \\ Rahman Dayani ${ }^{2}$
}

\begin{abstract}
The bad economic conditions make competition in the business world becomes more intense, so that this makes employers continuously improve their efforts to achieve company goals. In order to achieve the goal, the company needs to try some marketing strategies such as product diversification, because the product diversification can increase consumer repurchase interest. To maintain the the interest, the company must also pay attention to the company's reputation as what has been done by UD Sabar Menanti to survive in the electronic market in Gerung while competitors retreated. This study is aimed at analyzing the significant effect of the variables of product diversification and of the variables of company reputation on the repurchase interest at UD Sabar Menanti in Gerung West Lombok. This research is associative research. Data are collected through a sample survey with purposive sampling technique of 100 respondents. Data are collected through observation, interview and a questionnaire. Data analysis method used is the structural analysis equation modelling with LISREL program version 8.80 . The first estimation showed that diversification of electronic products significantly affect direct repurchase interest. The second estimation indicated that both variables of product diversification and company reputation and the interaction did not significantly affect the repurchase interest. Thus it is concluded that product diversification variable positively and significantly affect the repurchase interest. While the variable of company reputation did not affect the the repurchase interest and could not moderate the relation between the company reputation and the repurchase interest in UD Sabar Menanti in Gerung West Lombok. It is suggested, then, that UD Sabar Menanti continue to develop product diversification in order to increase the repurchase interest.
\end{abstract}

Keywords: product diversification, company reputation, repurchase interest. 


\section{TMM JURNAL MAGISTER MANAJEMEN UNIVERSITAS MATARAM \\ Maret 2015}

\section{PENDAHULUAN}

\subsection{Latar Belakang}

Keadaan perekonomian yang semakin sulit menyebabkan persaingan di berbagai bidang kehidupan semakin ketat, termasuk didalamnya persaingan dalam dunia bisnis. Hal ini memacu pengusaha untuk memperbaiki usahanya agar tetap dapat mencapai tujuan perusahaan. Baik itu untuk memperoleh laba optimal, mengembangkan perusahaan ataupun memperkuat posisi dalam menghadapi pesaing.

Untuk mencapai tujuan tersebut perusahaan tidak dapat terlepas dari kegiatan pemasaran yang merupakan kegiatan pokok yang harus dilakukan untuk mencapai tujuan perusahaan baik tujuan jangka pendek maupun tujuan jangka panjang. Pemasaran berdasarkan definisi yang diberikan Asosiasi Pemasaran Amerika adalah "satu fungsi organisasi dan seperangkat proses untuk menciptakan, mengomunikasikan, dan menyerahkan nilai kepada pelanggan dan mengelola hubungan pelanggan dengan cara yang menguntungkan organisasi dan para pemilik saham" (Kotler dan Keller, 2006:6).

Agar dapat tumbuh dan berkembang dengan baik, maka perusahaan harus dapat mengantisipasi perkembangan ekonomi yang semakin kompetitif dengan melakukan strategi pemasaran yang tepat. Salah satunya adalah dengan melakukan diversifikasi produk. Diversifikasi produk adalah upaya yang dilakukan perusahaan untuk memasarkan beberapa produk yang sejenis dengan produk yang sudah dipasarkan sebelumnya (Lauren, 2012)

Effendi (1996:109) mengemukakan bahwa diversifikasi produk didefinisikan sebagai suatu perluasan pemilihan barang dan jasa yang dijual oleh perusahaan dengan jalan menambah produk baru atau jasa ataupun memperbaiki tipe, warna, mode, ukuran, jenis dari produk yang sudah ada dalam rangka memperoleh laba maksimal..

Varadarajan dalam (Ferdinand, 2002) pada studinya mengenai produk diversity dan kinerja perusahaan menemukan bahwa diferensiasi dan diversifikasi produk diakui dan diadopsi secara sungguh-sungguh oleh kebanyakan perusahaan sebagai basis strategi pemasaran untuk menghasilkan kinerja pasar yang baik. Sebab pada dasarnya konsumen yang puas atas suatu produk cenderung akan melakukan pembelian ulang produk yang sama (Dharmmesta, 1999). Dengan demikian perhatian perusahaan terhadap strategi diversifikasi produk seharusnya juga meningkatkan minat konsumen untuk membeli ulang produkproduk yang ditawarkan perusahaan.

Jika perusahaan mampu memberikan kepuasan kepada konsumennya melalui pelayanan dalam penyediaan banyak variasi produk yang dibutuhkan maka tidak menutup kemungkinan hal tersebut akan meningkatkan minat beli ulangnya (Kunjtara, 2007). Minat beli ulang pada dasarnya adalah perilaku pelanggan dimana pelanggan merespons positif 


\section{TMM JURNAL MAGISTER MANAJEMEN UNIVERSITAS MATARAM \\ Maret 2015}

terhadap kulitas pelayanan suatu perusahaan dan berniat melakukan kunjungan kembali atau mengkonsumsi kembali produk perusahaan tersebut (Cronin, dkk.,1992).

Model lain dikemukakan oleh Bentler dan Spencer dalam (Kunjtara, 2007) yaitu adanya perilaku masa lampau yang dapat mempengaruhi minat secara langsung dan perilaku mengkonsumsi ulang pada waktu yang akan datang. Penelitian lain yang dilakukan oleh Howard dan Sheth dalam (Kunjtara, 2007) memperlihatkan adanya variabel tanggapan (response variabel) yaitu keputusan untuk membeli, dimana konsumen yang puas akan melakukan konsumsi ulang pada waktu yang akan datang dan memberitahukan orang lain atas kinerja produk atau jasa yang dirasakannya.

Minat beli ulang merupakan bagian dari komponen perilaku dalam sikap mengkonsumsi. Meningkatnya minat beli konsumen tentu akan berbanding lurus dengan pencapaian tujuan perusahaan dalam jangka pendek yaitu mengoptimalkan laba. Selain itu tidak menutup kemungkinan juga untuk mencapai tujuan jangka panjang seperti tumbuh dan berkembang dengan munculnya minat beli ulang dari konsumen.

Perusahaan yang ingin konsumen membeli ulang produknya, harus memperhatikan juga reputasinya. Karena menurut Zeithaml dan Shapiro dalam (Selnes, 1993) konsumen sebenarnya juga memperhatikan berbagai informasi mengenai perusahaan atau korporasi, dan bagaimana pengalamannya atas penggunaan produk yang dihasilkannya. Ketika konsumen mempunyai pengalaman yang baik atas penggunaan berbagai jenis, merek, ukuran dan tipe produk yang ditawarkan oleh sebuah perusahaan, maka konsumen akan memberikan citra positif atas perusahaan tersebut. Dengan adanya informasi yang positif tentang perusahaan diharapkan akan menambah kepercayaan pelanggan kepada perusahaan. Sekaligus kesediaan mereka untuk membeli produk-produk yang ditawarkan perusahaan. Sebab, seperti yang dinyatakan oleh Anderson (1994) dalam (Kuntjara, 2007), reputasi perusahaan akan menstimulasi terjadinya pembelian ulang oleh pelanggan.

Purba (2005) dalam penelitiannya mengemukakan bahwa dengan melakukan strategi diversifikasi tipe produk akan memperkuat reputasi perusahaan. Sementara Oetomo (2009) mengatakan bahwa diversifikasi produk dalam bentuk keragaman menu berpengaruh positif terhadap minat beli ulang konsumen. Sedangkan Kuntjara (2007) menemukan bahwa reputasi perusahaan termasuk salah satu faktor yang mempengaruhi minat beli ulang konsumen. Berdasarkan hasil penelitian tersebut, penelitian kali ini akan mencoba mengaitkan ketiganya yaitu diversifikasi produk, reputasi perusahaan dan minat beli ulang konsumen. Karena belum banyak diteliti terutama dalam industri produk elektronik, maka penelitian kali ini akan menganalisis bagaimana pengaruh diversifikasi produk elektronik terhadap reputasi perusahaan dan minat beli ulang konsumen.

UD. Sabar Menanti merupakan sebuah usaha yang bergerak di bidang penjualan bahan bangunan dan barang-barang elektronik. Usaha ini didirikan pada tahun 1991 oleh pemiliknya yang bernama $\mathrm{H}$. Muhammad Amin dan saat ini memiliki 8 orang karyawan. Awalnya toko ini hanya menjual bahan bangunan saja, kemudian sejak 9 tahun yang lalu tepatnya tahun 2005 barulah mulai menjual barang-barang elektronik. Selama kurang lebih 4 tahun menjadi satu-satunya toko elektronik di Gerung, toko ini mulai merasa terancam 


\section{TM JURNAL MAGISTER MANAJEMEN UNIVERSITAS MATARAM \\ Maret 2015}

dengan hadirnya beberapa toko elektronik baru seperti toko Star Elektro dan Global sekitar tahun 2009 di daerah Gerung. Sejak saat itu, persaingan dirasakan semakin ketat sehingga perusahaan mulai melakukan strategi untuk mempertahankan dan menciptakan pasar baru dengan melakukan diversifikasi produk elektronik. Agar tidak mengalami kemunduran ataupun tergeser dari persaingan yang semakin ketat.

Hingga akhir tahun 2012, di Gerung sudah ada lima toko elektronik selain Toko Star Elektro dan Global, pada tahun 2011 lalu Toko Sukses dan Jaya Sentosa juga mulai membuka usaha elektronik di daerah Gerung. Namun kehadiran kedua toko baru tersebut belum mempengaruhi jumlah penjualan pada UD. Sabar Menanti. Sampai pada pertengahan 2013 lalu, kedua toko elektronik yang baru tersebut tutup. Padahal saat itu penjualan produk elektronik di Gerung dirasakan UD. Sabar Menanti cukup lancar. Saat ini di Gerung hanya ada tiga toko elektronik yaitu UD. Sabar Menanti, Star Elektro dan Global.

Secara umum semua toko elektronik di daerah Gerung menyediakan jenis produk elektronik yang sama antara lain Televisi, DVD, Lemari Es, Mesin Cuci, Kipas Angin, Speaker, Dispenser, Magic Jar/Com, Blender, Mixer dll. Tetapi UD. Sabar Menanti menyediakan produk elektronik yang jauh lebih banyak dan lebih beragam baik dari segi jenis, tipe, merek, warna dan ukuran produk.

\subsection{Tujuan Penelitian}

Untuk menganalisis pengaruh variabel diversifikasi produk elektronik terhadap minat beli ulang dengan reputasi perusahaan sebagai variabel moderator pada UD. Sabar Menanti di Gerung Lombok Barat.

\section{KAJIAN PUSTAKA}

\subsection{Penelitian Terdahulu}

Pada dasarnya tujuan dari suatu bisnis adalah untuk menciptakan kepuasan pelanggan. Salah satu strategi yang bisa dilakukan pelaku bisnis untuk mencapai tujuan ini adalah dengan melakukan diversifikasi produk. Dengan melakukan diversifikasi produk, konsumen akan merasa diberikan lebih banyak variasi pilihan atas suatu produk yang dibutuhkan, sehingga akan merasa puas untuk menentukan pilihannya. Selain memberikan kepuasan untuk memilih, strategi diversifikasi produk juga akan memperkuat reputasi perusahaan (Purba, 2005). Kuatnya reputasi positif perusahaan akan memberikan beberapa manfaat antara lain memberikan kepercayaan bagi konsumen yang baru pertama kali mengetahui tentang perusahaan, menjadi dasar yang baik bagi pembelian ulang oleh konsumen dan membentuk suatu rekomendasi dari mulut-ke mulut yang menguntungkan bagi perusahaan. Oetomo (2009) mengatakan bahwa diversifikasi produk dalam bentuk keragaman menu berpengaruh positif terhadap minat beli ulang konsumen. Kemudian Kuntjara (2007) menemukan bahwa reputasi perusahaan termasuk salah satu faktor yang mempengaruhi minat beli ulang konsumen. Berdasarkan hasil penelitian terdahulu tersebut, penelitian kali ini akan mencoba mengaitkan ketiganya yaitu diversifikasi produk, reputasi perusahaan dan minat beli ulang konsumen. 


\section{TMM JURNAL MAGISTER MANAJEMEN UNIVERSITAS MATARAM Maret 2015}

\subsection{Kajian Teori}

\subsubsection{Minat Beli Ulang}

Minat beli merupakan kecenderungan konsumen untuk membeli suatu merek atau mengambil tindakan yang berhubungan dengan pembelian yang diukur dengan tingkat kemungkinan konsumen melakukan pembelian.

Menurut Howard (1994) dalam Durianto dan Liana (2004:44) minat beli adalah sesuatu yang berhubungan dengan rencana konsumen untuk membeli produk tertentu serta berapa banyak unit produk yang dibutuhkan pada periode tertentu. Minat beli (willingness to buy) dapat didefinisikan sebagai kemungkinan bila pembeli bermaksud untuk membeli produk (Doods, Monroe dan Grewal,1991, dalam Yoestini dan Eva Sheilla, 2007). Rossiter dan Percy (1998) dalam Macdonald dan Byron Sharp (2003) mengemukakan bahwa minat beli merupakan instruksi diri konsumen untuk melakukan pembelian atas suatu produk, melakukan perencanaan, mengambil tindakan-tindakan yang relevan seperti mengusulkan (pemrakarsa), merekomendasikan (influencer), memilih dan akhirnya mengambil keputusan untuk melakukan pembelian.

Minat beli konsumen oleh beberapa peneliti terdahulu sering digunakan sebagai indikator kesuksesan suatu produk di pasar. Dalam penelitiannya Samu dalam (Sutantio, 2004) menunjukkan bahwa salah satu indikator bahwa suatu produk perusahaan sukses atau tidaknya di pasar adalah seberapa jauh tumbuhnya minat beli konsumen terhadap produk tersebut. Sementara itu Mital dalam (Sutantio, 2004) mengatakan bahwa salah satu indikasi sukses tidaknya suatu produk adalah besarnya minat membeli konsumen terhadap produk yang bersangkutan.

Sementara itu minat beli ulang pada dasarnya adalah perilaku pelanggan dimana pelanggan merespons positif terhadap kulitas pelayanan suatu perusahaan dan berniat melakukan kunjungan kembali atau mengkonsumsi kembali produk perusahaan tersebut (Cronin, dkk.,1992). Sementara itu (Fornell, 1992) menyatakan bahwa konsumen atau pelanggan yang puas akan melakukan kunjungan ulang pada waktu yang akan datang dan memberitahukan kepada orang lain atas jasa yang dirasakannya.

Meningkatnya minat beli ulang konsumen akan berbanding lurus dengan pencapaian tujuan perusahaan baik tujuan jangka pendek maupun jangka panjang. Dengan munculnya minat beli ulang, maka akan membuka peluang lebih besar bagi perusahaan untuk memperoleh laba yang optimal. Jika minat beli ulang konsumen ini dapat dipertahankan perusahaan, maka tidak menutup kemungkinan akan mendorong perusahaan untuk terus tumbuh dan berkembang.

Model lain dikemukakan oleh Bentler dan Spencer dalam (Kuntjara, 2007) yaitu adanya perilaku masa lampau yang dapat mempengaruhi minat secara langsung dan perilaku mengkonsumsi ulang pada waktu yang akan datang. Penelitian lain yang dilakukan oleh Howard dan Sheth dalam (Kuntjara, 2007) memperlihatkan adanya variabel tanggapan (response variabel) yaitu keputusan untuk membeli, dimana konsumen yang puas akan 


\section{TMU JURAL MAGISTER MANAJEMEN UNIVERSITAS MATARAM Maret 2015}

melakukan konsumsi ulang pada waktu yang akan datang dan memberitahukan orang lain atas kinerja produk atau jasa yang dirasakannya.

Oliver dkk (1993) juga mengatakan bahwa dalam banyak penelitian yang membahas mengenai kepuasan konsumen atau pelangan terlihat adanya hubungan yang positif antara kepuasan dan pembelian ulang, dimana apabila konsumen memperoleh kepuasan akan pelayanan dan jasa yang dikonsumsi maka akan cenderung untuk melakukan konsumsi ulang.

Dari beberapa pendapat ahli tersebut disimpulkan bahwa minat beli ulang merupakan keinginan untuk membeli kembali dimasa yang akan datang ataupun mengambil tindakan yang relevan seperti merekomendasikan apa yang sudah diperoleh baik berupa produk ataupun jasa kepada orang lain yang timbul setelah konsumen merasa puas atas jasa yang diterima dan mengambil keputusan untuk membeli produk tertentu.

Menurut Kotler dan Keller (2003:181), customer buying decision - all their experience in learning, choosing, using, even disposing of a product yang kurang lebih memiliki arti minat beli konsumen adalah sebuah perilaku konsumen dimana konsumen mempunyai keinginan dalam membeli atau memilih suatu produk, berdasarkan pengalaman dalam memilih, menggunakan dan mengkonsumsi atau bahkan menginginkan suatu produk.

Menurut Kotler dan Keller (2003:186) the consumer may also form an intention to buy the most preffered brand yang berarti bahwa konsumen mempunyai keinginan untuk membeli suatu produk berdasarkan pada sebuah merek.

Menurut Boyd, Walker, dan Larreche (2000:6-7), seseorang menginginkan produk, merek, dan jasa tertentu untuk memuaskan kebutuhan. Selain itu keinginan orang juga dibentuk oleh pengaruh sosial, sejarah masa lalu, dan pengalaman konsumsi.

\subsubsection{Diversifikasi Produk}

Diversifikasi merupakan upaya yang dilakukan oleh perusahaan untuk mengembangkan usahanya dengan jalan memasarkan beberapa produk baru yang berkaitan dengan inti bisnis ataupun tidak untuk melayani pasar yang sama ataupun berbeda.

Tjiptono (2008:132) mengemukakan definisi dari diversifikasi produk yaitu upaya mencari dan mengembangkan produk atau pasar yang baru, atau keduanya, dalam rangka mengejar pertumbuhan, peningkatan penjualan, profitabilitas dan fleksibilitas. Dari definisi di atas terlihat kesamaan pendapat mengenai tujuan diversifikasi yaitu perluasan atau penambahan terhadap barang dan jasa untuk meningkatkan profitabilitas perusahaan. 


\section{TMM JURNAL MAGISTER MANAJEMEN UNIVERSITAS MATARAM \\ Maret 2015}

Kotler (2001:69) menyatakan konsep diversifikasi produk merupakan salah satu cara untuk meningkatkan kinerja bisnis yang ada dengan jalan mengidentifikasi peluang untuk menambah bisnis menarik yang tidak berkaitan dengan bisnis perusahaan saat ini.

Diversifikasi Produk adalah upaya yang dilakukan perusahaan untuk memasarkan beberapa produk yang sejenis dengan produk yang sudah dipasarkan sebelumnya. Atau dengan kata lain diversifikasi produk merupakan kegiatan yang dilakukan perusahaan dengan menganekaragamkan produk awal yang ditawarkan menjadi beberapa produk lain yang sejenis.

Effendi (1996:109) mengemukakan bahwa diversifikasi produk didefinisikan sebagai suatu perluasan pemilihan barang dan jasa yang dijual oleh perusahaan dengan jalan menambah produk baru atau jasa ataupun memperbaiki tipe, warna, mode, ukuran, jenis dari produk yang sudah ada dalam rangka memperoleh laba maksimal.

Dari berbagai pendapat ahli tersebut dapat disimpulkan bahwa diversifikasi produk merupakan jalan atau strategi perusahaan yang berkaitan dengan produk mengenai cara menambahkan jenis produknya atau melakukan penganekaragaman untuk memperluas target pasar sehingga memberikan keuntungan lebih besar bagi perusahaan.

Diversifikasi produk perlu dilakukan oleh perusahaan agar tidak bergantung pada salah satu dari jenis barang saja. Dengan adanya diversifikasi produk, perusahaan dapat mengantisipasi penurunan permintaan atas salah satu jenis barangnya dengan barang lain yang sejenis (Kotler dan Keller, 2007). Selain itu diversifikasi produk juga merupakan salah satu cara untuk meningkatkan volume penjualan. Dan dapat mempengaruhi minat beli ulang konsumen (Oetomo, 2009) sekaligus memperkuat reputasi perusahaan (Purba, 2005).

Mengacu pada pendapat Effendi (1996:109), seperti yang tertulis pada latar belakang dalam penelitian ini hanya akan menganalisis pengaruh diversifikasi produk elektronik yang diukur dari variabel jenis produk, merek produk, ukuran produk dan tipe produk terhadap reputasi perusahaan dan minat beli ulang.

\subsubsection{Reputasi Perusahaan}

Reputasi perusahaan merupakan persepsi atas perusahaan oleh orang-orang baik yang berada di dalam ataupun di luar perusahaan (Yoestini, 2003). Menurut pendapat Doney dan Cannon (1997) dalam (Kuntjara, 2007) reputasi perusahaan merupakan keterkaitan perusahaan dengan sejarah atau riwayat perusahaan terutama atas dasar aktivitas usaha dengan pihak lain. Dari riwayat tersebut pelanggan dapat memperoleh beberapa informasi penting seperti hubungan kerja sama apa saja yang memiliki kualitas hubungan baik. Sehingga dengan adanya informasi riwayat perusahaan tersebut, jika informasi tersebut baik atau positif diharapkan akan dapat menambah kepercayaan pelanggan kepada perusahaan tersebut. 


\section{JMM JUVRNA M MASISTER MANASEEEN UNIVERSITAS MATARAM \\ Maret 2015}

Tidak hanya berpengaruh sampai disini, lebih jauh lagi diharapkan adanya kesediaan dari pelanggan tersebut untuk membeli produk-produk yang ditawarkan perusahaan kepada mereka. Hal ini dinyatakan oleh Anderson (1994), bahwa reputasi perusahaan akan menstimulasi terjadinya pembelian ulang oleh pelanggan.

Menurut Zeithml (1988) kualitas jasa yang dirasakan dari suatu produk atau jasa erat hubungannya dengan reputasi yang diasosiasikan dengan nama merek. Artinya pelanggan hanya akan mengasosiasikan suatu produk atau jasa dengan mereknya, dan karenanya reputasi perusahaan juga dapat diukur pada tingkatan produk atau jasa.

Selness (1993) menyatakan bahwa dalam industri jasa dan bisnis, merek seringkali dikaitkan dengan reputasi perusahaan daripada produk atau jasa itu sendiri. Berarti kualitas yang diterima dari sebuah produk atau jasa adalah berhubungan dengan reputasi perusahaan yang digabungkan dengan nama merek produk atau jasanya.

Menurut Dick, Chakravarty dan Biehal (1990) melalui penelitiannya mengemukakan suatu bukti bahwa reputasi perusahaan secara langsung membentuk kepercayaan pelanggan terhadap produk atau jasa dari perusahaan yang bersangkutan sehingga akan mempengaruhi pelanggan dalam menentukan pilihan.

Brown dan Dacin dalam (Subhan, 2006) menyatakan bahwa reputasi perusahaan sangat penting dari sudut pandang pelanggan untuk memberikan gambaran terhadap kualitas produk atau jasa yang dihasilkan. Lebih lanjut Sullivan dalam (Subhan, 2006) membuktikan bahwa reputasi dari perusahaan dalam sudut pandang pelanggan dapat dijadikan jaminan bagi pelanggan untuk menilai kualitas produk atau jasa yang diberikan oleh perusahaan.

Pembinaan reputasi merupakan sebuah proses jangka panjang antara perusahaan dengan pelanggan. Namun yang harus diperhatikan adalah dasar sebuah hubungan dipengaruhi dari aksi dan tindakan, kegiatan dan maupun kata-kata yang diucapkan oleh perusahaan atau orang-orang yang berada di dalam perusahaan (Herbig, 1994). Anderson (1994) menyatakan bahwa perilaku dan kepercayaan pelanggan dipengaruhi oleh pengalaman mereka di masa lalu. Pelanggan dengan pengalaman di masa lalu yang sedikit atau bahkan tidak memiliki pengalaman masa lalu sebelumnya dengan perusahaan, akan mempunyai perilaku dan kepercayaan berdasarkan atas reputasi perusahaan tersebut.

Herbig, dkk. (1994:26) menyatakan bahwa reputasi perusahaan dapat dilihat dari kompetensi perusahaan tersebut dan keunggulannya dibandingkan para perusahaan kompetitor yang lain. Sedang Moorman dan Miner (1997) membuktikan bahwa keberhasilan perusahaan secara maksimal dapat dicapai apabila perusahaan tersebut fokus terhadap bisnis intinya (core business) karena dengan kefokusan tersebut akan menunjukkan kompetensi intinya (core competencies) sehingga membuat pelanggan percaya terhadap keahlian perusahaan yang tercermin dalam pengetahuan dan pengalaman perusahaan tersebut dalam bisnis yang telah dijalaninya. 


\section{$J M M$ UNRAM \\ JURNAL MAGISTER MANAJEMEN UNIVERSITAS MATARAM \\ Maret 2015}

Berdasarkan beberapa teori tersebut, dapat disimpulkan bahwa reputasi perusahaan merupakan hasil dari keterkaitan perusahaan dengan riwayat perusahaan melalui berbagai aktifitas dimasalalu yang akan menjadi sebuah acuan bagi para partner bisnis untuk mengumpulkan informasi yang akan mempengaruhi kepercayaannya terhadap perusahaan dan berdampak pada minat dari konsumen untuk melakukan pembelian ulang.

Untuk dapat mencapai tujuan jangka panjang, perusahan harus benar-benar memperhatikan reputasinya. Karena jika reputasi perusahaan buruk, maka akan sangat sulit sekali untuk tumbuh dan berkembang pada bidang usaha apapun. Oleh karena itu, banyak hal dilakukan oleh perusahaan untuk dapat menguatkan dan meningkatkan reputasinya.

Mengacu pada pendapat Anderson (1994); Herbig dkk (1994) serta Moorman dan Miner (1997) diketahui bahwa reputasi perusahaan akan menstimulasi minat beli ulang. Dan variabel reputasi perusahaan memiliki indikator antara lain: kompetensi perusahaan, keunggulan perusahaan, kepercayaan pelanggan terhadap perusahaan dan pengalaman perusahaan.

\section{METODE PENELITIAN}

Jenis penelitian yang digunakan dalam penelitian ini adalah penelitian asosiatif, yaitu suatu jenis penelitian yang bertujuan untuk mengetahui hubungan antara dua variabel atau lebih. Metode pengumpulan data yang digunakan adalah sampel survey. Menurut (Nazir,2005) Sampel Survey adalah suatu prosedur dimana hanya sebagian populasi saja yang diambil dan dipergunakan untuk menentukan sifat serta ciri yang dikehendaki populasi. Teknik pengambilan sampel dilakukan dengan menggunakan Purposive Sampling, yaitu pengambilan sampel secara sengaja sesuai dengan persyaratan sampel yang diperlukan.. Dalam hal ini bertemu ditempat penelitian. Jumlah responden 100 orang. Teknik pengumpulan data yang digunakan adalah observasi, wawancara dan angket menggunakan kuesioner. Pengujian data dengan uji validitas, reliabililtas dan uji asumsi klasik dengan bantuan program SPSS. Dan metode analisis data yang dipergunakan adalah analisis stuctural equation modeling dengan bantuan program LISREL 8.80.

\section{HASIL DAN PEMBAHASAN}

Untuk melakukan analisis data dengan metode SEM diperlukan beberapa tahap pengujian tertentu yang hasilnya sebagai berikut:

\subsection{Uji Kebaikan Model (Goodness Of Fit)}

Tabel 4.1.1. Goodness of Fit Index

\begin{tabular}{|l|c|c|c|}
\hline \multicolumn{1}{|c|}{ Goodness of Fit Index } & Hasil & Cut Off Value & Kriteria \\
\hline Likelihood Chi Square & 32,08 & Diharapkan kecil & \\
\hline P-Value & 0,24 & $\geq 0,05$ & Baik \\
\hline CMIN/DF & 1,0025 & $\leq 3,00$ & Baik \\
\hline RMSEA & 0,044 & $\leq 0,08$ & Baik \\
\hline
\end{tabular}

Jurnal Magister Manajemen UNRAM

Maret 2015 


\section{TM JURNAL MAGISTER MANAJEMEN UNIVERSITAS MATARAM Maret 2015}

\begin{tabular}{|l|c|c|c|}
\hline GFI & 0,95 & $\geq 0,90$ & Baik \\
\hline AGFI & 0,89 & $\geq 0,90$ & Tidak Baik \\
\hline RFI & 0,81 & $\geq 0,90$ & Tidak Baik \\
\hline CFI & 0,97 & $\geq 0.90$ & Baik \\
\hline
\end{tabular}

Dari tabel hasil output 4.21 dapat dilihat bahwa model ini sudah memenuhi kriteria goodness of fit dimana nilai Chi Square yang dihasilkan 32,08 dengan nilai P-value $0,24>0,05$. Kriteria goodness of fit lainnya juga sudah memenuhi syarat yang direkomendasikan.

The minimum Sampel Discrepancy Funcion - CMIN/DF merupakan indeks kesesuaian parsimonious yang mengukur hubungan goodnes of fit model dan jumlah koefisien-koefisien yang diestimasi yang diharapkan untuk mencapai tingkat kesesuaian. Hasil CMIN/DF sebesar 1,0025 yang nilainya lebih kecil dari nilai yang direkomendasikan CMIN/DF $<3$, sehingga menunjukkan model fit yang baik.

Berdasarkan analisis terhadap goodnes of fit - GFI mencerminkan tingkat kesesuian model secara keseluruhan. Tingkat penerimaan yang direkomendasikan GFI $>0,90$. Hasil menunjukkan nilai GFI sebesar 0,95>0,90 sehingga model memiliki fit yang baik.

Adjusted Goodness of fit Index - AGFI sebagai pengembangan indeks GFI, merupakan indeks yang telah disesuaikan dengan rasio degree of freedom model yang diusulkan dengan dengan degree of fredom dari null model. Hasil penelitian menunjukkan nilai AGFI sebesar 0,89 yang nilainya lebih kecil dari nilai AGFI yang direkomendasikan $>0,90$ sehingga menunjukkan bahwa model ini memiliki fit yang tidak baik.

Relative Fit Indices-RFI merupakan alternatif incremental fit index yang membandingkan model yang diuji dengan baseline. Nilai yang direkomendasikan sebagai tingkat kesesuaian yang baik adalah $\geq 0,90$ sementara hasil penelitian menunjukkan bahwa nilai RFI sebesar 0,81 sehingga dapat dinyatakan bahwa tingkat kesesuaian berada pada kriteria tidak baik.

Comparative Fit Index - CFI , merupakan indeks kesesuaian incremental yang membandingkan model yang diuji dengan model null. Nilai yang direkomendasikan CFI $\geq$ 0,90. Hasil pengujian sebesar 0,97, menunjukkan bahwa model adalah baik.

The Root Mean Square Error of Approximation - RMSEA, indeks yang digunakan untuk mengkompensasi chi square statistics dalam sampel yang besar. Nilai RMSEA menunjukkan goodnes of fit yang dapat diharapkan bila model diestimasi dalam populasi. Nilai penerimaan yang direkomendasikan $\leq 0,08$. Hasil pengujian sebesar 0,044 sehingga menunjukkan bahwa model adalah baik.

Dari hasil pengukuran goodness of fit index di atas, dapat disimpulkan sebagian besar parameter telah memenuhi persyaratan yang diharapkan, dan hanya dari AGFI dan RFI saja yang tidak memenuhi syarat sehingga secara keseluruhan telah memenuhi persyaratan goodness of fit. Hal ini sesuai dengan pendapat Ghozali (2006) yang menyatakan jika ada sebagian parameter Goodness of Fit yang tidak memenuhi syarat, dapat dilihat dari parameter yang lain, dan jika terdapat beberapa parameter yang telah memenuhi persyaratan maka dapat dinyatakan bahwa model telah memenuhi asumsi Goodness of Fit.

\subsection{Hasil Pengujian Hipotesis}

Jurnal Magister Manajemen UNRAM

Maret 2015 


\section{$J M M$ UNRAM \\ JURNAL MAGISTER MANAJEMEN UNIVERSITAS MATARAM \\ Maret 2015}

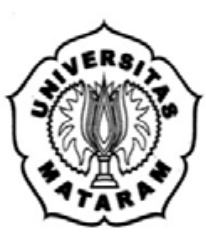

Hipotesis penelitian dilakukan uji satu sisi, karena hubungan antar variabel independen dengan variabel dependen dihipotesiskan berpengaruh positif. Untuk mengetahui apakah hipotesis didukung oleh data atau tidak, maka nilai t statistik yang diperolah dibandingkan dengan 1,96. Apabila t statistik lebih dari 1,96 maka dapat disimpulkan bahwa hipotesis penelitian didukung oleh data (terbukti secara signifikan) begitu pula sebaliknya. Hasil pengujian terhadap model penelitian diperoleh hasil sebagai berikut:

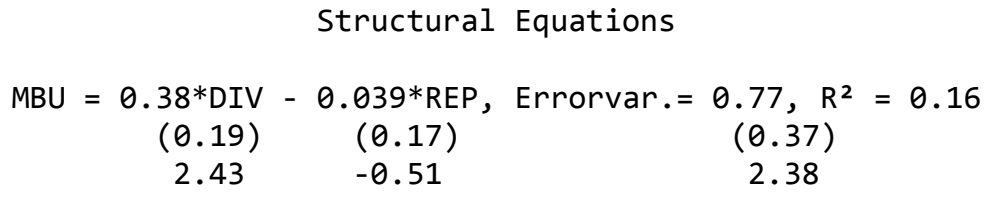

Berdasarkan hasil estimasi tersebut dapat dilihat bahwa diversifikasi produk elektronik berpengaruh langsung terhadap minat beli ulang dengan nilai $t$ statistik yang dihasilkan 2,43 $>1,96$. Artinya, hipotesis pertama yaitu diduga bahwa variabel dalam diversifikasi produk seperti jenis produk, merek produk, ukuran produk dan tipe produk berpengaruh signifikan terhadap minat beli ulang pada UD. Sabar Menanti diterima.

Structural Equations

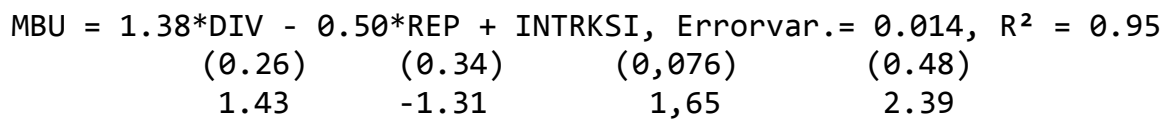

Lebih lanjut berdasarkan hasil estimasi kedua tersebut dapat dilihat bahwa variabel diversifikasi produk tidak berpengaruh signifikan terhadap minat beli ulang dengan nilai $\mathrm{t}$ statistik yang dihasilkan $1,43<1,96$. Dan untuk variabel reputasi ternyata juga tidak berpengaruh signifikan terhadap minat beli ulang dengan nilai $t$ statistik $-1,31<1,96$. Artinya, hipotesis kedua yaitu diduga bahwa variabel reputasi perusahaan berpengaruh signifikan terhadap minat beli ulang pada UD. Sabar Menanti ditolak.

Kemudian yang terakhir variabel interaksi yang merupakan hasil penjumlahan variabel diversifikasi produk (X) dengan reputasi perusahaan (Y) dengan rumus $(\mathrm{X} 1+\mathrm{X} 2+\mathrm{X} 3+\mathrm{X} 4)(\mathrm{Z} 1+\mathrm{Z} 2+\mathrm{Z} 3+\mathrm{Z} 4)$ didapatkan hasil yang sama yaitu tidak berpengaruh signifikan terhadap minat beli ulang dengan nilai $t$ statistik $1,65<1,96$. Jadi dapat disimpulkan bahwa variabel reputasi perusahaan tidak dapat memoderasi hubungan antara diversifikasi produk dengan minat beli ulang. Hal ini berarti bahwa hipotesis terakhir yaitu diduga bahwa variabel dalam diversifikasi produk seperti jenis produk, merek produk, ukuran produk, dan tipe produk sebelum mempengaruhi minat beli ulang pada UD. Sabar Menanti didahului dengan meningkatkan reputasi perusahaan ditolak.

\subsection{PEMBAHASAN}

\subsubsection{Pengaruh Diversifikasi Produk Terhadap Minat Beli ulang}

Pada bab sebelumnya telah dikemukakan hipotesis alternatif pertama yaitu : Diduga bahwa variabel dalam diversifikasi produk seperti jenis produk, merek produk, ukuran produk dan tipe produk berpengaruh signifikan terhadap minat beli ulang pada UD. Sabar 


\section{TMM JURNAL MAGISTER MANAJEMEN UNIVERSITAS MATARAM \\ Maret 2015}

Menanti. Hasil pengujian seperti yang telah dijelaskan bagian hasil pengujian hipotesis, menunjukkan bahwa hipotesis ini diterima atau terbukti. Artinya diversifikasi produk seperti jenis produk, merek produk, ukuran produk dan tipe produk berpengaruh positif dan signifikan terhadap minat beli ulang konsumen pada UD. Sabar Menanti. Jika dilihat dari nilai bobot pengaruh langsung yang bernilai positif menunjukkan bahwa semakin baik diversifikasi produk yang dilakukan perusahaan maka konsumen akan semakin berminat untuk melakukan pembelian ulang.

Hasil penelitian kali ini sama dengan hasil penelitian sebelumnya yang dilakukan oleh Afifah (2008) dan Oetomo (2009) dimana kembali dibuktikan bahwa ternyata memang benar diversifikasi produk yang dilakukan oleh perusahaan dapat meningkatkan minat beli bahkan minat beli ulang konsumen secara signifikan. Baik dilakukan pada industri jasa seperti kuliner dan properti pada penelitian terdahulu maupun industri produk elektronik sebagaimana yang diteliti pada penelitian kali ini.

\subsubsection{Pengaruh Reputasi Perusahaan Terhadap Minat Beli Ulang}

Pada bab sebelumnya telah dikemukakan hipotesis alternatif kedua yaitu : Diduga bahwa variabel reputasi perusahaan berpengaruh signifikan terhadap minat beli ulang pada UD. Sabar Menanti. Hasil pengujian seperti yang telah dijelaskan bagian hasil pengujian hipotesis, menunjukkan bahwa hipotesis ini ditolak atau tidak terbukti. Artinya reputasi perusahaan tidak berpengaruh terhadap minat beli ulang konsumen pada UD. Sabar Menanti.

Hasil penelitian kali ini berbeda dengan hasil penelitian sebelumnya yang dilakukan oleh Kuntjara (2007) dimana pada penelitian sebelumnya diperoleh hasil bahwa minat beli ulang konsumen dipengaruhi salah satunya dengan reputasi perusahaan. Sementara pada penelitian kali ini diperoleh hasil yang bertolak belakang, yaitu reputasi perusahaan tidak mempengaruhi minat beli ulang. Hasil penelitian kali ini juga tidak dapat membuktikan teori yang dikemukaan oleh Anderson (1994) mengenai reputasi perusahaan yang akan menstimuli terjadinya pembelian ulang oleh pelanggan.

\subsubsection{Pengaruh Diversifikasi Produk Terhadap Minat Beli Ulang Dengan Reputasi Perusahaan sebagai Moderator}

Pada bab sebelumnya telah dikemukakan hipotesis alternatif terakhir yaitu : Diduga bahwa variabel dalam diversifikasi produk seperti jenis produk, merek produk, ukuran produk dan tipe produk sebelum mempengaruhi minat beli ulang pada UD. Sabar Menanti didahului dengan meningkatkan reputasi perusahaan. Hasil pengujian yang telah dijelaskan bagian hasil pengujian hipotesis, menunjukkan bahwa hipotesis ini ditolak atau tidak terbukti. Artinya diversifikasi produk elektronik sebelum berpengaruh terhadap minat beli ulang konsumen pada UD. Sabar Menanti tidak didahului dengan meningkatkan reputasi perusahaan. Hasil penelitian kali ini menunjukkan bahwa diversifikasi produk berpengaruh secara langsung terhadap minat beli ulang pada UD. Sabar Menanti.

Hasil penelitian kali ini berbeda dengan hasil penelitian sebelumnya yang dilakukan oleh Purba (2005) dimana pada penelitian sebelumnya diperoleh hasil bahwa diversifikasi 


\section{TM JURNAL MAGISTER MANAJEMEN UNIVERSITAS MATARAM \\ Maret 2015}

produk elektronik sebelum mempengaruhi volume penjualan didahului dengan memperkuat reputasi perusahaan. Sementara pada penelitian kali ini diperoleh hasil yang bertolak belakang, yaitu diversifikasi produk elektronik berpengaruh signifikan terhadap minat beli ulang konsumen tanpa didahului dengan meningkatkan reputasi perusahaan. Oleh karena itu penelitian kali ini tidak dapat membuktikan bahwa reputasi perusahaan dapat menjadi variabel moderator antara diversifikasi produk dengan minat beli ulang pada UD. Sabar Menanti.

\section{KESIMPULAN DAN SARAN}

\subsection{Kesimpulan}

Berdasarkan hasil pengujian dan analisis yang dilakukan pada Bab sebelumnya, maka hasil penelitian ini dapat disimpulkan sebagai berikut:

5.1.1. Diversifikasi produk elektronik yang dilakukan oleh UD. Sabar Menanti melalui penganekaragaman jenis produk, merek produk, ukuran produk, dan tipe produk terbukti berpengaruh positif signifikan terhadap minat beli ulang konsumennya.

5.1.2. Reputasi perusahaan yang diukur dari kompetensi perusahaan, keunggulan perusahaan, kepercayaan pelanggan terhadap perusahaan dan pengalaman perusahaan ternyata tidak berpengaruh terhadap minat beli ulang pada UD. Sabar Menanti. Hal ini terjadi karena konsumen berniat melakukan pembelian ulang lebih didasarkan pada keragaman produk elektronik yang ditawarkan bukan pada reputasi perusahaan.

5.1.3. Reputasi perusahaan tidak dapat dijadikan variabel moderator antara diversifikasi produk dengan minat beli ulang pada UD. Sabar Menanti. Karena hasil penelitian membuktikan bahwa diversifikasi produk elektronik yang dilakukan UD. Sabar Menanti melalui penganekaragaman jenis produk, merek produk, ukuran produk, dan tipe produk terbukti secara langsung mempengaruhi minat beli ulang konsumen tanpa didahului dengan meningkatkan reputasi perusahaan.

\subsection{Saran}

Berdasarkan kesimpulan tersebut, maka dapat dirumuskan saran sebagai berikut:

5.2.1. UD. Sabar Menanti harus terus meningkatkan usahanya dengan melakukan diversifikasi produk dengan lebih baik lagi. Karena diversifkasi produk yang dilakukan sudah terbukti dapat meningkatkan minat beli ulang konsumen yang tidak hanya memberi keuntungan laba tapi juga akan membantu perusahaan untuk tumbuh dan berkembang. Berdasarkan hasil pengumpulan data yang telah dilakukan, penulis menyarankan agar UD. Sabar Menanti menambah ragam merek produk yang dijual, 


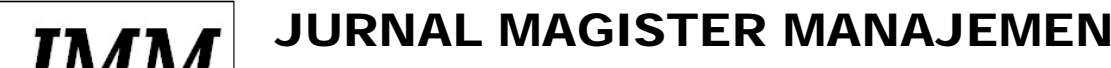 UNIVERSITAS MATARAM Maret 2015}

karena beberapa responden merasa merek-merek yang ada masih kurang terutama untuk merek-merek produk buatan Cina yang relatif murah.

5.2.2. UD. Sabar Menanti tetap perlu menjaga reputasi perusahaannya agar terus baik. Karena reputasi perusahaan akan dapat menciptakan citra positif yang akan menjadi acuan bagi konsumen ataupun orang untuk percaya terhadap perusahaan. Meskipun pada penelitian ini reputasi perusahaan tidak bisa dibuktikan mampu meningkatkan minat beli konsumen pada UD. Sabar Menanti.

\subsection{Keterbatasan dan Arah Penelitian Selanjutnya}

5.3.1 Variabel diversifikasi produk yang diteliti pada penelitian ini hanya diukur dari empat indikator yaitu jenis produk, merek produk, ukuran produk dan tipe produk saja. Pada penelitian selanjutnya diharapkan dapat menambah jumlah indikator yang mengukur diversifikasi produk, salah satunya dengan menambah indikator warna produk.

5.3.2. Pada penelitian ini, variabel reputasi perusahaan dijadikan sebagai variabel moderator, dan hasilnya reputasi perusahaan tidak dapat memoderasi hubungan antara diversifikasi produk dan minat beli ulang. Oleh karena itu, penelitian selanjutnya dapat mencoba untuk menguji kembali sebagaimana penelitian ini dilakukan ataupun merubah variabel reputasi perusahaan menjadi variabel terikat, artinya diversifikasi akan mempengaruhi dua variabel sekaligus yaitu reputasi perusahaan dan minat beli ulang.

5.3.3. Penelitian ini menggunakan jumlah sampel minimal yaitu hanya 100 orang responden, sehingga diharapkan pada penelitian selanjutnya dapat menambah jumlah sampel lebih banyak lagi agar hasil uji yang dilakukan lebik baik lagi.

\section{DAFTAR PUSTAKA}

Afifah, Noor. 2008. Pengaruh Diversifikasi Produk Dan Pemberian Potongan Harga Terhadap Minat Beli Konsumen Di Rumah Makan Carita Gresik. Skripsi pada Universitas Muhammadiyah Gresik: tidak diterbitkan

Anderson, E.W., C. Fornell, dan R.R. Lehmann. 1994. "Customer satisfaction, market share and profitability : Findings for Sweden". Journall of Marketing, Vol. 58, No.1 : 5356.

Boyd, Walker dan Larreche. 2000. Manajemen Pemasaran : Suatu Pendekatan Strategis dengan Orientasi Global, Edisi Kedua.Jakarta : Erlangga

Cronin Jr, J. J. and S. A. Taylor (1992). Measuring service quality: a reexamination and extension. The Journal of Marketing: 55-68.

Dharmmesta, B. S. 1999. Loyalitas Pelanggan: Sebuah Kajian Konseptual Sebagai Panduan Bagi Peneliti. Jurnal Ekonomi dan Bisnis Indonesia. Vol. 14. No 3.

Durianto,Darmadi \& Liana,Cecilia. 2004. Analisis efektifitas iklan televisi "Softener Soft \& Fresh" di Jakarta dan sekitarnya menggunakan consumer decision model. Jurnal ekonomi perusahaan : Vol 11 no 1 ISSN:0854 - 8153

Effendi, R. 1996. Marketing Manajemen. Malang : IKIP Malang

Engel, J. F., Blackwell, R. D., Miniard, P. W. 1993. Consumer Behavior. Edisi 8. Texas: The Dryden Press. 


\section{$J M M$ UNRAM \\ JURNAL MAGISTER MANAJEMEN UNIVERSITAS MATARAM \\ Maret 2015}

Ferdinand, Augusty. 2002. Pengembangan Minat Beli Merek Ekstensi. Semarang:Badan Penerbit Universitas Diponegoro.

.2002.Kualitas Strategi Pemasaran: Sebuah Studi Pendahuluan. Jurnal Sains Pemasaran Indonesia, Vol. I, No.1, (Mei),p.107-119

Fornell, Claes. 1992. A National Customer Satisfaction Barometer: The Swedish Experience. Journal of Marketing. Vol 56

Ghozali dan Fuad. 2005. Structural equation modeling Teori Konsep \& Aplikasi dengan Program Lisrel 8.54. Badan Penerbit UNDIP. Semarang.

Guiltinan, Joseph P. \& Gordon W. Paul. 1992. Manajemen Pemasaran. Jakarta:Erlangga.

Herbig, Paul, John Milewichz \& Jim Golden, 1994, A Model of Reputation Building \& Destruction, Journal of Business Research, Vol. 31

James F. Engel,dll. 1995. Perilaku Konsumen, cetakan 1. Penerbit: Binarupa Aksara: Jakarta

Kotler, Philip. 2001. Manajemen Pemasaran : Analisis, Perencanaan, Implementasi, dan Kontrol. Jakarta : PT. Prehallindo

\& Keller K. Lane.2006. Manajemen Pemasaran. Jakarta: Ghalia.Indonesia . 2013. "Marketing Management", 14 th edition, Upper Saddle River, NJ:Prentice Hall Inc

\& Kevin Lane Keller. 2007. Manajemen Pemasaran. Jakarta: PT.Indeks Gramedia.

Kunjtara. 2007. Analisis Faktor-Faktor yang Mempengaruhi Minat Beli Ulang Konsumen. Tesis Magister Manajemen Universitas Diponegoro: tidak diterbitkan

Latan,Hengky. 2012.Stuctural Equation Modeling Konsep dan Aplikasi Menggunakan Program Lisrel 8.80. Bandung: Alfa Beta

Lauren, Adrian. 2012. Melaksanakan strategi pemasaran melalui strategi diversifikasi produk dalam menghadapi era globalisasi. Diunduh pada tanggal 1 Oktober 2014 dari: http://ardianlauren.wordpress.com/2012/01/15/melaksanakan-strategi-pemasaran-melalui-strategidiversifikasi-produk-dalam-menghadapi-persaingan-di-era-globalisasi/

Macdonald, Emma., Sharp, Byron. (2003). Management Perceptions of the Importance of Brand Awareness as an Indication of Advertising Effectiveness. Marketing Bulletin, 14, Article 2. Reprinted from Marketing Research On-Line, 1996, 1, 1-15

Nazir, Moh. 2005. Metodologi Penelitian. Jakarta: Ghalia Indonesia.

Oetomo, Ali. 2009. Analisis Pengaruh Keragaman Menu, Persepsi Harga dan Lokasi terhadap Minat Beli Ulang Konsumen. Jurnal Ekonomi: tidak diterbitkan

Oliver, Richard. 1993. A Conceptual Model of Service Quality and Service Satisfaction; Compatible Goal, Different Concept, in Advance in Service Marketing and Management.Vol 2; p. 65 - 85

Purba, Jan Horas V. 2005. Strategi Diversifikasi Produk Terhadap Tingkat Omzet Penjualan (Studi Kasus Pada PT/ Surya Pelita Pratama). Jurnal Ilmiah Ranggagading: Volume 5. No.1.

Schiffman,Leon.G. dan Kanuk,Leslie.2007.Perilaku Konsumen.Jakarta: PT Indeks

Selnes, Fred. 1993. An Examination of the Effect of Product Performance on Brand Reputation, Satisfaction and Loyalty. European Journal of Marketing. Vol.27. No 9. 


\section{TM JURNAL MAGISTER MANAJEMEN UNIVERSITAS MATARAM Maret 2015}

Subagyo,Ahmad. 2010. Marketing In Business. Studi Kasus UMK \& LKM, Edisi Pertama, Penerbit : Mitra Wacana Media.Jakarta

Subhan, Muh. 2006. Analisis faktor-faktor yang berpengaruh terhadap reputasi suatu perusahaan. Tesis Program Study Magister Management. Universitas Diponegoro: tidak diterbitkan

Sugiyono. 2004. Statistik Untuk Penelitian. Bandung : CV Alfabeta

Sunyoto,Danang.2012.Dasar-Dasar Manajemen Pemasaran,Cetakan 1. Penerbit PT. Buku Seru:Jakarta.

Sutantio, Magdalena. 2004. Studi Mengenai Pengembangan Minat Beli Merek Ekstensi:Studi Kasus Produk Sharp di Surabaya. Jurnal Sains Pemasaran Indonesia, Vol.III

Tjiptono, Fandy. 2008. Strategi Pemasaran. Edisi ketiga. Penerbit Andi:Yogyakarta.

Uma Sekaran, 2006, Metodologi Penelitian untuk Bisnis. Edisi 4. Buku 2. Jakarta: Salemba Empat.

Yoestini dan Eva Sheila. R. 2007. Jurnal Sains Pemasaran Indonesia. Vol VI (No. 3), p261p276 